\title{
The Transition of Joint Stock Companies in Slovenia: Shareholder-Value Approach versus Stakeholder- Value Approach
}

Matej Lahovnik*

Abstract:

In the shareholder theory of firms, the company's assets are the property of the shareholders, and managers are viewed as agents of the shareholders with all of the enforcement difficulties associated with agency relationships, but without legal obligations to any other stakeholder. An alternative view is the stakeholder theory of firms. The standard principal-agent paradigm can be expanded to the stakeholder agency problem. In this view, managers can be seen as the agents of all stakeholders. From the perspective of social responsibility, enlightened organizations view the internal and external environment as a variety of stakeholders.

This paper offers some insights into the characteristics of the corporate governance system in Slovenia. Its focus is on the relationship between governance and management. The authors tried to determine in their research the roles of various groups of stakeholders in Slovenian companies. The paper's conclusions are based on a longitudinal research method. The paper is the result of three consecutive research studies on the characteristics of corporate governance in Slovenia over the period from 1998 to 2006. The paper compares the results from studies conducted in 1998 and 2002 with the latest results in 2006. The most important long-term strategic objective of Slovenian companies is growth. The share of Slovenian companies - excluding equity opportunity costs - has decreased significantly in the last six years due to the consolidation of ownership structures. The controlling owners are more active in setting the required rate of return on their equity investments. There is no conflict of interest between internal and external shareholders in most companies. Obviously, Slovenian companies have changed their strategic behaviour to reflect the interests of their stakeholders. It may be argued that some stakeholders, like customers and employees, are even more important for Slovenian managers than the owners.

Keywords: corporate governance, shareholders, stakeholders, transition

\section{Introduction}

From the perspective of social responsibility, enlightened organizations view the internal and external environment as a variety of stakeholders (Daft, Marcis, 2001, p.118). Effective corporate governance ensures that long-term strategic objectives and plans are established, and that the proper management and management structures are in place to achieve those objectives, while at the same time making sure the structure functions to maintain the corporation's integrity, reputation, and accountability to its relevant constituencies. In recent times, more than half of the states in the US have passed stakeholders laws, which permit or even require directors to consider the impact of their actions on constituencies other than shareholders, including employees, customers,

* Matej Lahovnik

Faculty of Economics, University of Ljubljana

e-mail: matej.lahovnik@ef.uni-lj.si 
suppliers, and the community. This is in contrast to the traditional model of a publicly held corporation which holds that corporate directors serve only one constituency - their shareholders (Monks, Minow, 2001, p.37).

One of the key questions regarding corporate governance concerns who should run the corporation. There are two basic economic theoretical approaches. The property-based concept of the firm has prevailed in the Anglo-Saxon world. In this theory, the company's assets are the property of the shareholders, and managers are viewed as agents of the shareholders with all of the enforcement difficulties associated with agency relationships, but without legal obligations to any other stakeholder. An alternative view is the stakeholder theory of the firm. The stakeholder theory approach has been applied to performance management theory. Its growing emphasis is on customer relationship management, and the firm's relationships with its employees, suppliers, investors and local community. The shareholder-value approach results from the Anglo-Saxon culture in economics, and therefore defines the economic mainstream. On the other hand, the stakeholder-value approach is a result of the economic culture in continental Europe. Some transition problems regarding joint stock companies in Slovenia may have been an unrecognized consequence of the question of which economic culture in Slovenia exists. Any pure adoption of a new approach to economy from a foreign economic culture causes problems if the new approach adopted is not compatible with the domestic economic culture.

The basic research question that should be examined is whether a process of convergence or divergence exists regarding comparison between corporate governance practices in Slovenia throughout its transition period and the most established theoretical paradigms of corporate governance. This paper intends to determine which of the two concepts of corporate governance theory prevails in Slovenia in practice: the property based concept of the firm, i.e. shareholder theory, or its alternative, i.e. stakeholder theory. Research objectives were defined on the theoretical and pragmatic level. The theoretical research should derive the general similarities and differences between the prevailing theoretical paradigms of corporate governance for the transitional economy and the identified corporate governance practices. The research findings offer new insights into the characteristics of the corporate governance system in Slovenia. Three consecutive research studies were conducted on the characteristics of corporate governance in Slovenia over the period from 1998 to 2006. This paper compares the results of the studies made in 1998 and 2002 with the latest results in 2006. The paper tries to determine the most important characteristics of the strategic behaviour of managers in Slovenia in the last period of transition and the changing pattern of corporate governance in Slovenia.

\section{Theoretical Background}

A corporation is a mechanism established to allow different parties to contribute capital, expertise, and labour for the maximum benefit of each. Corporations offer a lasting and resilient social structure (Monks, Minow, 2001, p. 11). In order to qualify as a moral agent, a corporation needs to embody a process of moral decision making. The perennial question is whether business can do well by doing good (Donaldson, 1982, p.30). Some companies have made social responsibility part of their marketing strategy. Consumers can feel less guilty about buying arguably decadent products if they know that by doing so they are supporting good causes. At one end of the scale are the most basic aspects of social responsibility, such as compliance with the law. At the other end of the scale are activities so unrelated to the goods and services sold that pursuing them is considered by the marketplace to be irrelevant to the company's productivity.

Proponents of corporate social responsibility have used four arguments to make their case: moral obligation, sustainability, license to operate, and reputation (Porter, 2004 , p. 81). However, studies of the effect of a company's social reputation on consumer purchasing preferences or on stock market performance have been inconclusive at best. Having no way to quantify the benefits of these investments puts corporate social responsibility programs on shaky ground, liable to be dislodged by a change of management or a swing in the business cycle.

In practice, it is possible to distinguish between three levels of company responsibility. The primary level comprises the company's responsibilities to meet its material obligations to shareholders, employees, customers, suppliers and creditors, to pay its taxes and to meet its statutory duties. The sanctions against failure to match up to these relatively easily definable and measurable responsibilities are provided by competition and the law. The next level of responsibility is concerned with the direct results of the actions of companies in 
carrying out their primary task and includes making the most of the community's human resources and avoiding damage to the environment. Beyond these two levels, there is a much less well defined area of responsibility regarding the interaction between business and society in a wider sense. On this level it is a question of how far business has a responsibility to maintain the framework of the society in which it operates and to what extent business should reflect society's priorities rather than its commercial interest. Other authors have also tried to develop a model for evaluating the social performance of companies (see Figure 1).

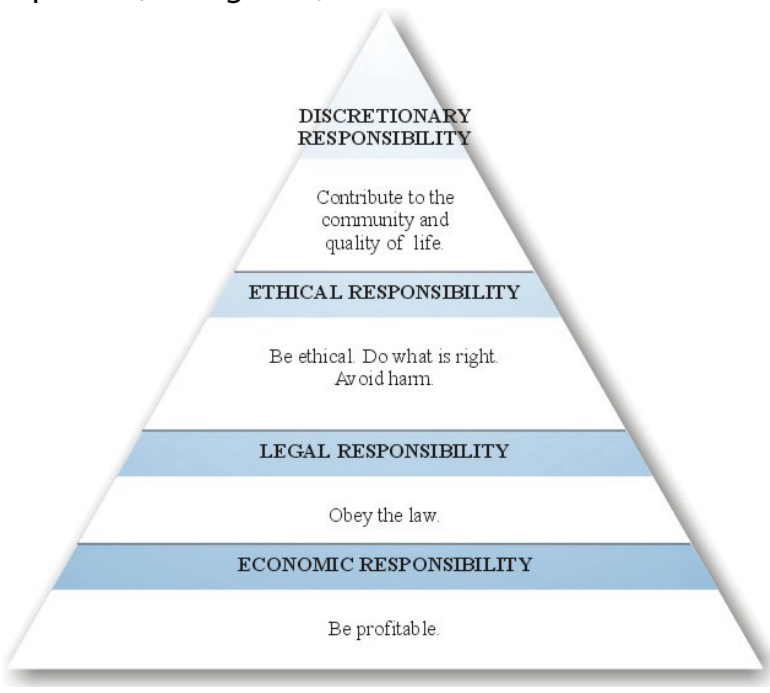

Figure 1: Model for evaluating corporate social performance

Source: Archie B. Carroll: The Pyramid of Corporate Social Responsibility: Toward the Moral Management of Corporate Stakeholders, Business Horizons, 34 (JulyAugust) 1991. Daft R., Marcic D.: Understanding Management, 2001, p. 122.

The key findings of a SIRAN analysis (SIRAN is the Sustainable Investment Research Analyst Network, a network that supports more than 220 analysts who specialize in integrating environmental, social, and governance research with investing) of the reporting practices companies in the S\&P 100 INDEX (www.socialinvest.org) include the following:

- More than half of the S\&P 100 Index (58 companies) have special sections of their websites dedicated to sharing information about their social and environmental policies and performance.

- Almost 40 percent of the S\&P 100 Index (39 companies) now issue annual corporate social responsibility reports.
- $24 \%$ of companies of the S\&P 100 Index say they base their corporate social responsibility reports on the widely recognized external standard provided by the Global Reporting Initiative's Sustainability Reporting Guidelines. 20\% of companies included an index of Global Reporting Initiative indicators in their reports. $6 \%$ of companies met the highest standard of reporting fully in accordance with the Global Reporting Initiative's Guidelines.

- Of those companies issuing annual Corporate Social Responsibility reports, $62 \%$ say their reports are based on Global Reporting Initiative standards, and $51 \%$ include an index to Global Reporting Initiative indicators.

The basis of a corporation's existence is wealth maximization. There is no such thing as a good corporation that is not completely profitable. Corporations live in a world where the market determines what people will buy and what they will pay. A corporation that does not produce goods that people want at a price they are willing to pay has no reason to exist. On the other hand, the public wants corporations to work with it to keep their workplaces and the environment safe. The public wants a continual sense of progress and growth from its corporations. The public wants its interest in the company, whether as shareholder, employee, customer, supplier, creditor or simply neighbor to be designed for the long-term. Moreover, managers should take care to satisfy the interests of their primary stakeholders. In theory, corporations support the free market, with as little interference from government as possible. In reality, whenever corporations can persuade the government to protect them from the free market, by legislating barriers to competition or limiting their ability, they do so. In practice, corporations have influenced government at least as much as government has influenced business (Monks, Minow, 2001, p. 16). Shareholders expect managers to run their business in a way that will encourage a supportive governmental and societal climate to capitalist enterprise.

The property-based concept of the firm has prevailed in the Anglo-Saxon world. The Chicago School of Law and Economics treats the company as a nexus of contracts through which the stakeholders regulate transactions between each other. In this theory, the company's assets are the property of the shareholders, and managers are viewed as agents of the shareholders with all of the enforcement difficulties associated with agency 
relationships, but without legal obligations to any other stakeholder. This view maintains that the rights of creditors, employees and others are strictly limited to statutory, contractual and common law rights (Allen, 1992). Any broadening of a company's social obligations is dangerous, according to this school of thought (Clarke, 1997, p. 185). Milton Friedman once said: "Few trends could so thoroughly undermine the foundations of our free society as the acceptance by corporate officials of a social responsibility other than to make as much money for their shareholders as possible" (1962, p. 113). Hayek added that, once the management of a corporation is regarded as not only being entitled but even obliged to consider in its decisions whatever is regarded as being of a social interest, it gains uncontrollable power. In this case, managers would become subject to the public interest $(1979$, p. 79). These views expressed by neoliberal economists strongly influenced the corporate governance system of the Anglo-Saxon world in the 1970s and 1980s. Managers were mostly oriented to short-term financial objectives such as sustaining share price and dividend payments at all costs. A substantial numbers of mergers and acquisitions in this period can be identified that were pursued to discipline managers. Monks and Minow (2001, p. 81) attempted to restate the essential principles of the shareholder theory of the firm. Their approach allows all other interests to be factored in without losing sight of the goal of long-term wealth maximisation. It is difficult enough to determine the performance of a company's strategy based on just one goal, namely shareholder value. It is impossible when other goals are added in. Therefore, the only way to determine a company's performance is to consider its long-term shareholder value (Clarke, 1997, p. 186).

The modern corporation typically has multiple owners who each intend to maximise their investment in the corporation. Owners become principals when they contract with executives to manage their firms on their behalf. Thus, in the modern corporation, agents and principals are motivated by opportunities for their own personal gain. Principals invest their wealth in companies and design the corporate governance mechanism in ways that maximise their utility. The chance that agents do not share the same interests and utility choices as their principals is substantial (Davis et al., 1997, p. 22). According to agency theory, it is difficult for principals to determine ex-ante which agents will self-aggrandise and so it is prudent for principals to limit potential losses to their utility (Williamson, 1985).
Some management studies have suggested that managers make different decisions when owners are actively involved in the firm (owner-controlled) versus situations where paid managers are relatively free to set the firm's strategy (Tosi, Katz, Gomez, 1997; McEachern, 1975). Thus, firms become controlled by managers when the firm's shares are so disparately owned that no single shareholder is able to effectively guide the decisions of managers. The objective in agency theory is to reduce the agency costs incurred by principals by imposing internal controls to keep the agent's self-serving behaviour in check. There are various internal and external (acquisitions, divestitures) corporate governance control mechanisms to prevent the agency problem. Two corporate governance mechanisms that have attracted substantial attention in the literature are alternative executive compensation schemes and governance structures.

An alternative view is the stakeholder theory of the firm. The philosophical antecedents of stakeholder theory date back to the 19th century, to the conception of cooperative movement and mutuality. In The Theory of the Growth of the Firm, Edith Penrose laid the intellectual foundations for stakeholder theory in her concept of the company as a bundle of human assets and relationships. In his work, Clark thoroughly described the development of the stakeholder theory approach (1997, pp. 186-187). Hill and Jones (1992) expanded the standard principalagent paradigm to the stakeholder agency problem. In this view, managers can be seen as the agents of all stakeholders. With the onset of knowledge-based competition (Buckley, Carter, 2000, pp. 55-71; Teece, 2000, pp. 35-54), this approach will be even more important in the near future. If knowledge is a predominant productive resource and most knowledge is created by and stored within individuals, then employees are also the primary stakeholders (Grant, 1997). The stakeholder theory approach has been applied to performance management theory. Its growing emphasis is on customer relationship management, and the firm's relationships with its employees, suppliers, investors and the local community. Some well-known approaches such as the European Foundation for Quality Management or the Balanced Scorecard system try to cover performance in all key relationships (Kaplan, Norton, 1996; European Foundations for Quality Management, 1993). The fundamental issue is how to satisfy the interests of more complex constituencies than shareholder theory might suggest. 
The traditional theory of the firm argues that the arguments advancing a constituency for corporate functioning are miscast. It is difficult enough to determine the success of a company's strategy based on only one goal - shareholder value. It is impossible when other goals are added in. The only way to evaluate the success of a company's performance is to consult those who have the most direct and wide-reaching interest in the results of that performance - the shareholders. Only owners have the motive to inform themselves and to enforce standards that arguably are a proxy for the public interest (Monks, Minow, 2001, p. 40).

\section{The Empirical Analysis Data Collection and Measurement}

The empirical research was based on an extensive questionnaire. After careful consideration, it was decided the best approach would be to interview top managers personally as the other techniques available could not really be considered appropriate to the problem at hand. 'Eye to eye' discussion enabled us to get additional insight into performance issues. The responses of the top managers were recorded on a standardised Likert scale. The empirical data was processed with SPSS 13, where emphasis was given to descriptive statistical analysis.

The empirical research was based on a fully-structured interview that was prepared with pre-coded responses. A firm had to have specific characteristics to fall within the research sample:

it should have had at least 250 employees;

it should have had at least USD 5 million in annual income; and

it should have been a joint-stock company.

This study is based on a research sample of 69 companies that met these criteria 2006. The study compares the results of studies made in 1998 and 2002 with the latest results in 2006. The studies in the years 1998 and 2002 were based on 71 companies.

In order to determine the dynamic of the strategic behaviour of managers in the last eight years, the study compared the top managers' values from research done in 2006 with research done by Kalacun in 2000. The results of the three longitudinal studies regarding the investment decisions of managers in the years 1998, 2002 and 2006 have been compared. The study tried to determine the most important characteristics of the strategic behaviour of managers in Slovenia in the last period of transition and the changing pattern of corporate governance in Slovenia.

\section{The Results of the Study}

By applying the deductive method, analysis, longitudinal comparison, method of elimination and synthesis, the theoretical basis needed for empirical investigation of corporate governance was developed. Internal owners control the majority-voting share in $34 \%$ of the companies (see Figure 2). The share of the state has been decreasing over the last eight years, yet it is still higher than in other EU member states.
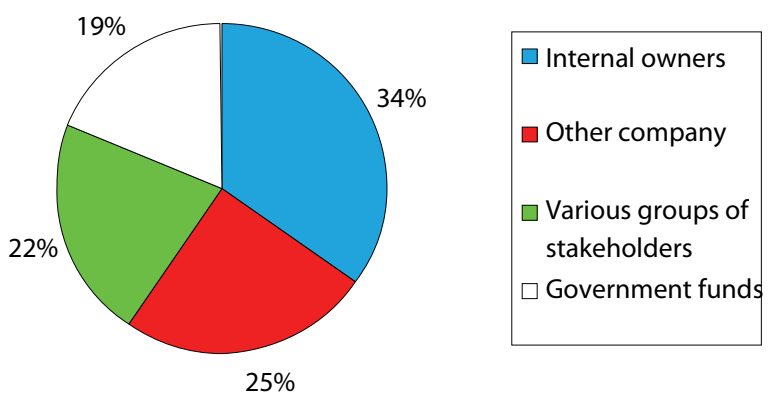

Figure 2: The most influential stakeholder in the process of corporate governance

In the first period of transition, 1991-1998, the consolidation of business activities was the most important strategic priority. On the other hand, growth has been the most important long-term strategic objective of Slovenian companies for the last eight years (see Figure 3). Creating value for shareholders is the most important long-term strategic objective in a relatively small number of companies. This finding could be problematic with regard to the problem of agency if the company is in a mature or even a declining industry. Jensen argued that the likelihood of the agency problem occurring is considerably greater in a declining industry. Instead of developing a consolidation strategy, managers are in many cases still oriented towards growth (1988, page 46). On the other hand, there will be a convergence of interests if an industry is growing. In such a case, the opportunities for growth within that industry usually also result in the maximisation of shareholder value. No company in the research sample would formulate the 
maximisation of employees' income as its key strategic objective. As already pointed out, the most important strategic objectives are not necessarily mutually exclusive. However, they somehow do show both strategic priorities and the stakeholder's influence on the corporate governance process.
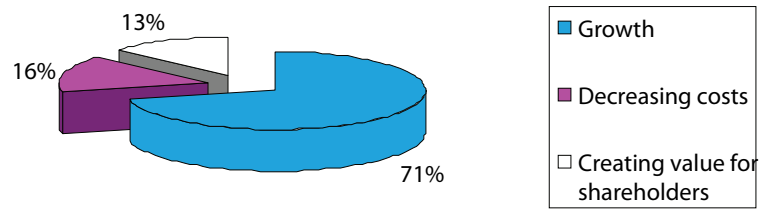

Figure 3: The most important long-term strategic objective

Customers have a significant impact on the strategic decisions of the companies involved in the research. This is very positive and reflects a long-term strategic partnership between companies and their key customers (see Figure 4). The role of the Supervisory Board is relatively less important than the Management Board. This can be explained by the two-tiered corporate governance system applied in Slovenia and may be compared with the European continental corporate governance system. It can be expected that the role of the Supervisory Board will become more important with the continuing consolidation of ownership structures. What is more, in the last months some companies decided to introduce the one-tiered corporate governance system to strengthen the role of owners when formulating strategy.

Profit-sharing and stock options are still not often used to motivate managers in the companies studied (see Table 1). The primary reason is the current tax system in Slovenia, which does not favour this kind of managerial reward. The second reason is that the biggest proportion of Slovenian managers' payments is traditionally fixed. In spite of this fact the increasing importance of variable payment instruments can be observed over the last few years. Where managers had their own set of objectives which did not coincide with those of the shareholders some measures would apply. The most common measure was the replacement of the management by the Supervisory Board. Some other measures against undisciplined management are also used (see Table 2).
Almost one fifth of companies do not have any measures for such a case. These companies are already controlled by their managers.

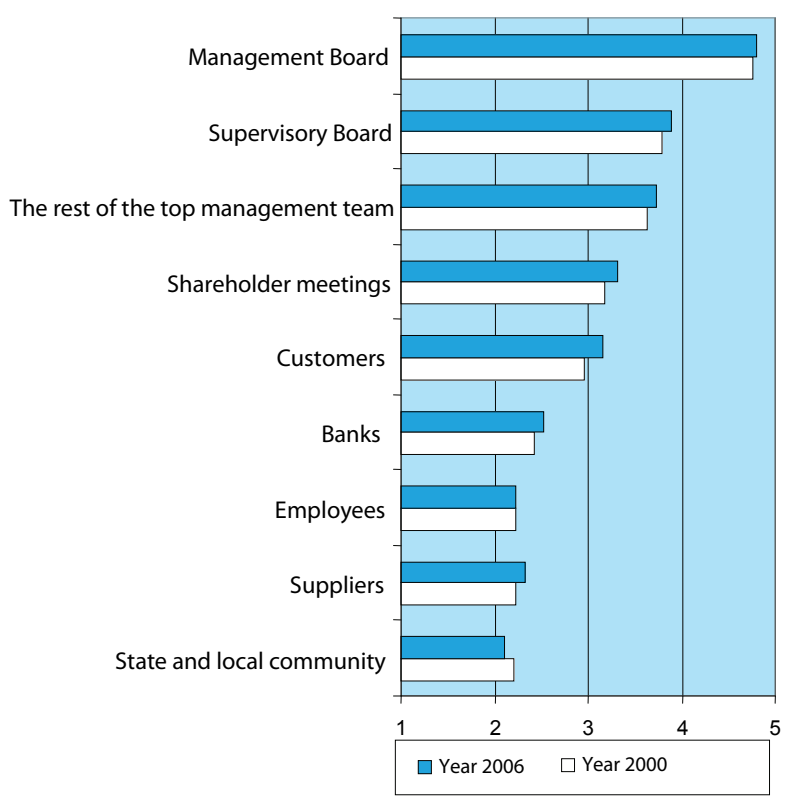

Scale: 1 - not at all important, 5- very important

Figure 4: The influence of stakeholders on the acceptance of key strategic decisions

\begin{tabular}{|l|c||c|}
\hline Motivation & $\begin{array}{c}\text { Share of } \\
\text { companies } \\
\text { (in \%) - Year } \\
\mathbf{2 0 0 0}\end{array}$ & $\begin{array}{c}\text { Share of } \\
\text { companies } \\
\text { (in \%) - Year } \\
\mathbf{2 0 0 6}\end{array}$ \\
\hline \hline Individual contract & 100 & 100 \\
\hline Various benefits & 43.5 & 51.5 \\
\hline Profit-sharing: cash & 30.4 & 34.4 \\
\hline Profit-sharing: stocks & 19.6 & 23.6 \\
\hline Stock options & 10.9 & 16.9 \\
\hline
\end{tabular}

Table 1: Managerial rewards 


\begin{tabular}{||l|c|c||}
\hline Sanction & $\begin{array}{c}\text { Share of } \\
\text { companies } \\
\text { (in \%) - Year } \\
\mathbf{2 0 0 0}\end{array}$ & $\begin{array}{c}\text { Share of } \\
\text { companies } \\
\text {-(in \%) - } \\
\text { Year 2006 }\end{array}$ \\
\hline \hline $\begin{array}{l}\text { Replacement of inefficient } \\
\text { management executed by } \\
\text { the Supervisory Board }\end{array}$ & 52.3 & 61.4 \\
\hline $\begin{array}{l}\text { Reducing payments } \\
\text { No sanction }\end{array}$ & 22.7 & 28.7 \\
\hline $\begin{array}{l}\text { Reducing or cancelling } \\
\text { profit-sharing }\end{array}$ & 18.2 & 12.2 \\
\hline $\begin{array}{l}\text { Replacement of inefficient } \\
\text { management executed by } \\
\text { shareholders at the } \\
\text { shareholders' meeting }\end{array}$ & 13.6 & 19.5 \\
\hline \begin{tabular}{l} 
Cancelling various benefits \\
\hline
\end{tabular} & 6.8 & 11.8 \\
\hline
\end{tabular}

Table 2: Measures for disciplining management in the case of an agency problem

In order to create value for shareholders, managers should consider the concept of "EVA" (the economic value added concept) (Miller, Dess, 1996, page 122). One problem of using traditional financial accounting information to measure profitability is that it does not take into account the opportunity cost of equity capital. Financial returns are crucial because of their importance to owners as a stakeholder group, so overlooking the owners' investment costs leads to serious oversight (McCrory, Gerstberger, 1992, page 33-38). Equity is often a very expensive source of capital and ignoring it misrepresents the amount of economic value the business is creating for its shareholders. Controlling owners are more active in setting the required rate of return on their equity investments. In over one-third of companies, managers assumed that in 2002 the opportunity cost on equity investment was $10 \%$, which was higher than the cost of long-term debt. The shares of such companies decreased in 2006 due to decreasing interest rates (see Figure 5).

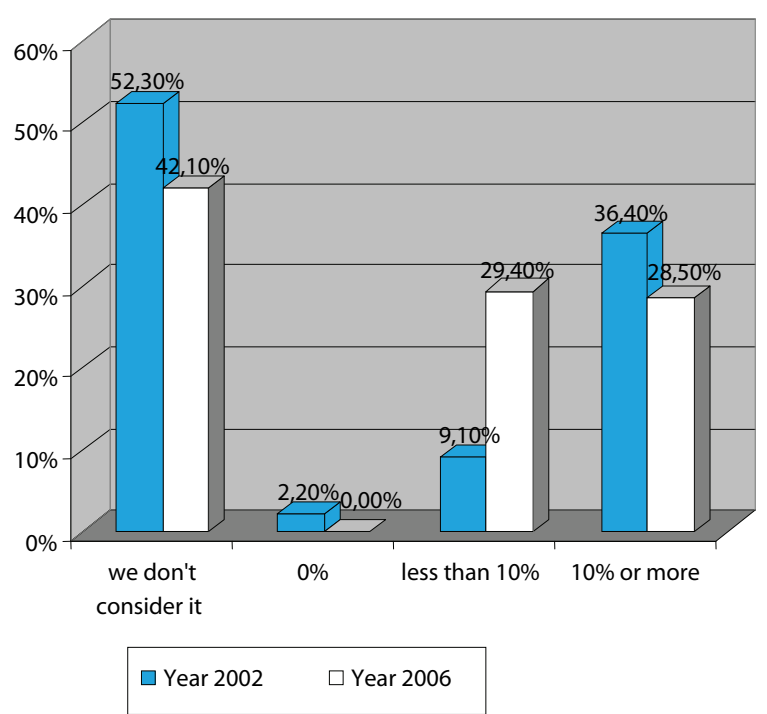

Figure 5: The opportunity cost of equity investment considered by managers when calculating the weighted average costs of capital

Managers and internal owners have managed to forge specific coalitions in many companies that are controlled by insiders. These companies are in fact controlled by managers and behave differently from companies controlled by strategic outside investors. An insiderdominated firm may generate neither the resources needed for restructuring activities, such as investment, nor have the incentive to sell the firm to outsiders who have those resources (Blanchard, Anghion, 1995). Prašnikar and Svejnar (1998, page 19) found some strong arguments in their research to support this thesis regarding the role of insiders in Slovenian companies. For example, in the cases of some takeover bids managers and the internal owners forged a specific coalition because they were afraid of losing their jobs. In such cases, the takeover bid failed even though it would have enhanced the competitive position of the merged company in the market. However, the fear of reorganisation and loss of jobs due to the sharing of activities between companies prevailed and there was no reselling of shares by internal owners to strategic outsiders.

The latest research conducted for this study from the year 2006 found that the most important value of the managers in Slovenia is growth and development of their companies (4.51), followed by customer satisfaction (4.49) and employee satisfaction (4.38). Profit maximisation (3.93) and shareholder value (3.84) are surprisingly less important, as well as ecological issues (3.81). By comparing these results with the earlier research done by 
Kalacun in 2000, it was found that managers in Slovenia have stable values (see Figure 6). Kalacun found in her research (2000, page 23) that the most important values of Slovenian managers are the following: growth and development of the company (4.59), customer satisfaction (4.47), employee satisfaction (4.41) and ecological issues (4.03). Therefore, it may be argued that some stakeholders, like customers and employees, are even more important for Slovenian managers than the owners.

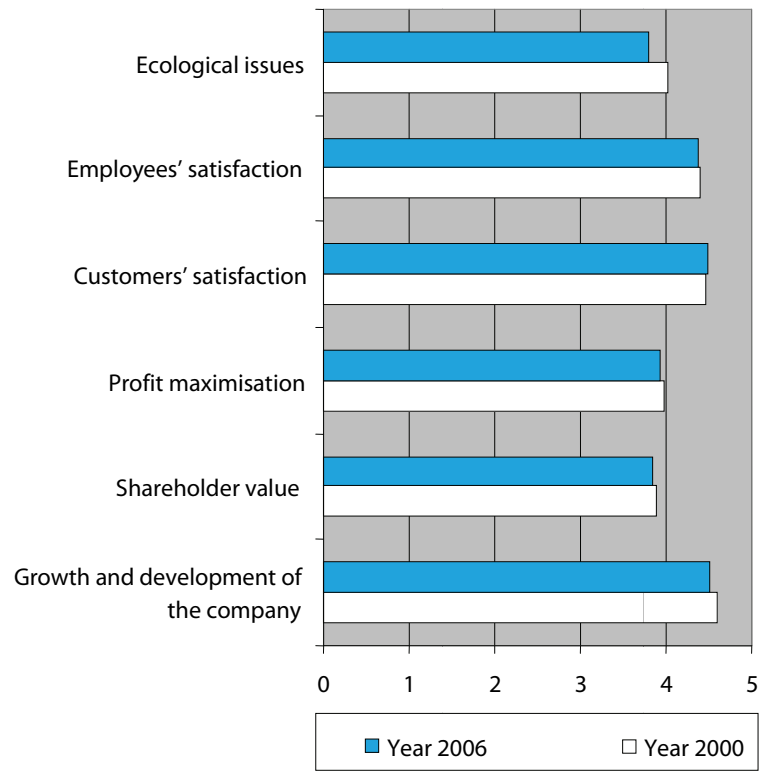

Scale: 1- not at all important, 5- very important

Figure 6: The most important values of Slovenian managers

\section{Conclusion}

The shareholder-value approach is a result of the Anglo-Saxon culture in economics and defines the economic mainstream. On the other hand, the stakeholder-value approach is a result of the economic culture in continental Europe. The important role of different stakeholders, such as employees and the local community, has been characteristic of the Slovenian economy for decades. Therefore, any pure adoption of a shareholder approach in an economy from a foreign economic culture causes problems. The strategic behaviour of Slovenian managers reflects the interests of their stakeholders. Therefore, it was found that customer satisfaction and employee satisfaction are very important values for Slovenian managers. The most important longterm strategic objective of Slovenian companies is growth and development. On the one hand, the share of Slovenian companies - excluding equity opportunity costs - has decreased significantly in the last eight years due to the consolidation of ownership structures. The controlling owners are more active in setting the required rate of return on their equity investments. On the other hand, customers have a significant impact on the strategic decisions of the companies involved in this study. This is very positive and reflects a long-term strategic partnership between companies and their key customers. According to the results of the research that has been conducted over the last few years for this paper, it can be argued that stakeholder theory is the leading corporate governance approach in Slovenia. Its growing emphasis is on customer relationship management, the firm's relationships with its employees and suppliers, as well as on partnership with the local community. ㄷ.

\section{References}

Aghion, P. and Carlin, W. 1997. Restructuring outcomes and the evolution of ownership patterns in Central and Eastern Europe, Lessons from the economic transition. Dordrecht: Kluwer Academic Publishers.

Allen, W. T. 1992. Our Schizophrenic Conception of the Business Corporation. Cardozo Law Review 14 (2): 261-282.

Blanchard, O. and Aghion, P. 1995. On Insider Privatisation. Boston: MIT Press.

Buckley, J. P. and Carter, J. M. 2000. Knowledge Management in Global Technology Markets. Long Range Planning 33 (1): 55-71.

Carroll, B. A. 1991. The Pyramid of Corporate Social Responsibility: Toward the Moral Management of Corporate Stakeholders. Business Horizons 34 (4): 34-42.

Clark, T. 1998. The Stakeholder Corporation: A Business Philosophy for the Information Age. Long Range Planning 31 (2): 182-194.

Daft, R. and Marcic, D. 2001. Understanding Management. London: Thomson Learning.

Davis, H. J., Schoorman, F. D. and Donaldson L. 1997. Toward a Stewardship Theory of Management. Academy of Management Review 22 (1): 20-47.

Donaldson, L. and Davis J. H. 1991. Stewardship theory or agency theory: CEO governance and shareholder returns. Australian Journal of Management 16 (1): 49-61.

Friedman, M. 1962. Capitalism and Freedom. Chicago: University of Chicago Press.

Grant, R. M. 1997. The Knowledged Based View of the Firm: Implications for Management Practice. Long Range Planning 30 (3): 450454.

Hayek, F. A. 1979. The Political Order of a Free People. Law, Legislation, Liberty 3 (1): 81-85.

Hill, C. W. and Jones, T. M. 1992. Stakeholder Agency Theory. Journal of Management Studies 29 (2): 131-154.

Jensen, C. M. 1988. Takeovers, Their Causes and Consequences. Journal of Economic Perspectives 2 (1): 21-48. 
Kalacun, S. 2000. Business Ethic in Slovenia. Ljubljana: Faculty of Economics.

Kaplan, R. S. and Norton, D. P. 1996. The Balanced Scorecard. Boston: Harvard Business School Press.

Katz, P. J. and Niehoff, P. B. 1998. How Owners Influence Strategy - A comparison of Owner-Controlled and Manager-Controlled Firms. Long Range Planning 31 (5): 755-761.

McEachern, W. 1975. Managerial Control and Performance. Lexington: Lexington Books.

McCrory, F. W. and Gerstberger P. 1992. The New Math of Performance Measurement. Journal of Business Strategy 10 (2): 33-38.

Miller, A. and Dess, D. G. 1996. Strategic Management. New York: The Mc Graw-Hill.

Monks, R. A. G. and Minnow, N. 2001. Corporate Governance. Oxford: Blackwell.

Penrose, E. 1959. The Theory of the Growth of the Firm. Oxford: Oxford University Press.

Porter, M. 2004. Strategy and Society. Harvard Business Review 82 (5): 80-92.

Prašnikar, J. and Svejnar, J. 1998. Investment, Wages and Ownership during the Transition to a Market Economy: Evidence from Slovenian Firms. Working Papers Series No. 79. Ljubljana: Faculty of Economics.

Teece, D. J. 2000. Strategies for Managing Knowledge Assets: the Role of Firm Structure and Industrial Context. Long Range Planning 33 (1): 35 54.

Tosi, H., Katz, J. and Gomez, L. M. 1997. Disaggregating the agency contract: The effects of monitoring, incentive alignment, and term in office on agent decision making. Academy of Management Journal 12 (3): 584-602.

Weston, J. F., Chung, S. K. and Hoag, E. S. 1990. Mergers, Restructuring and Corporate Control. New Jersey: Prentice-Hall.

Williamson, O. E. 1985. The economic institutions of capitalism: Firms, markets, relational contracting. New York: Free Press. 